\title{
Fecaloma gigante
}

\section{Giant fecaloma}

\section{Marco Antonio Ayala-García ${ }^{1,2}$, Daniel Tafoya ${ }^{3}$, Karina Itzel Martínez ${ }^{3}$}

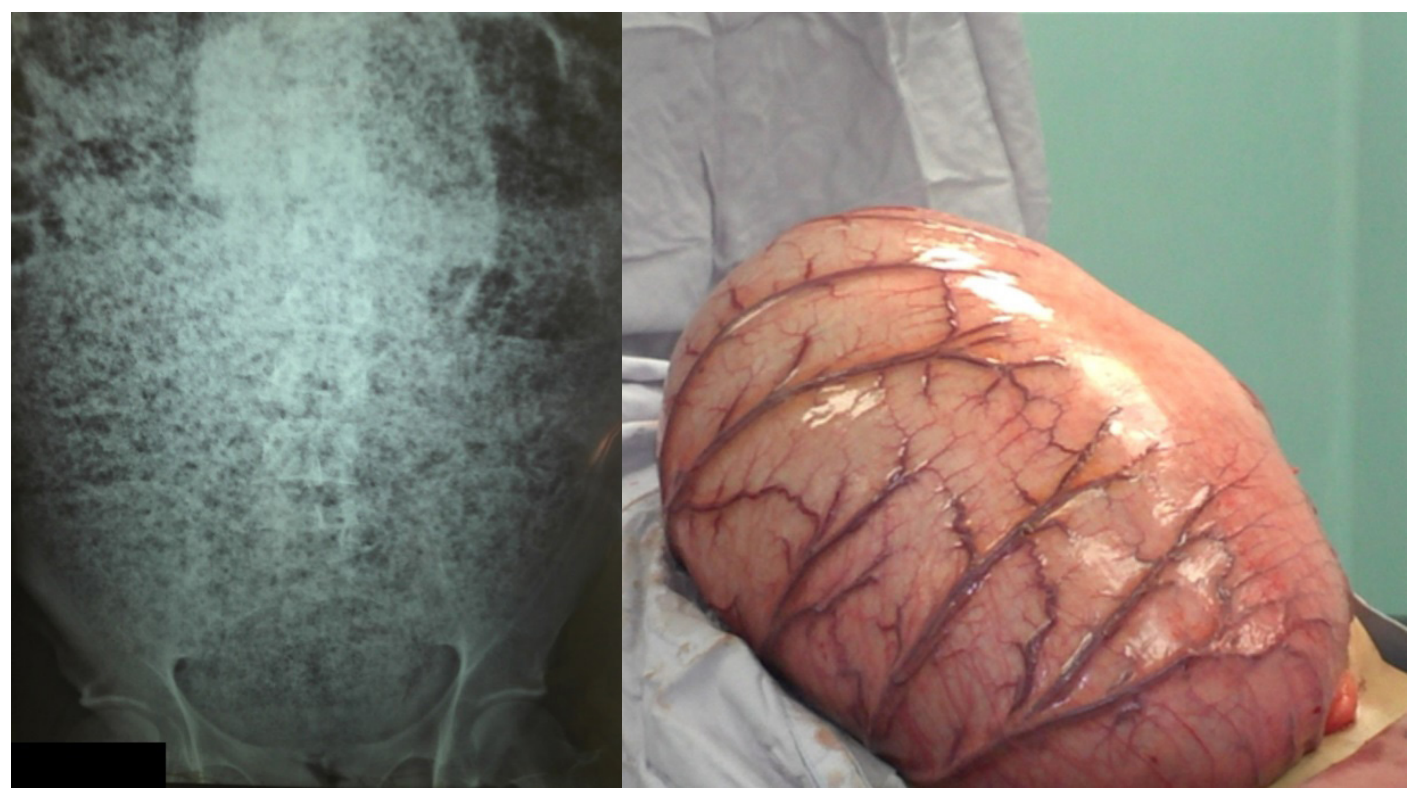

Varón de 23 años, quien acudió a urgencias con dolor abdominal, vómito y ausencia de evacuaciones de 15 días de evolución. A la exploración tenía distensión abdominal, matidez a la percusión y al tacto rectal "masa" de consistencia firme no móvil. Se realizó laparotomía, encontrándose dilatación del sigmoides ocupado por excremento de consistencia firme, con un volumen de $6000 \mathrm{~cm}^{3}$. El resto del colon era normal y se encontraba vacío. Se resecó el sigmoides con la "masa" y se realizó colostomía del descendente y cierre distal. Diagnóstico: Enfermedad de Hirschsprung.

A 23-year old male patient attended the emergency room with abdominal pain, vomiting and constipation for 15 days. The physical examination revealed abdominal distention; dullness on percussion of the abdomen and a firm non-motile mass was felt on the rectal examination. A laparotomy was performed finding that the sigmoid colon was fully occupied by fecal material with a total volume of $6,000 \mathrm{~cm} 3$. The rest of the colon was normal and was empty of fecal material. A sigmoid resection was performed with colostomy of the descendent colon and distal closure. The diagnosis was Hirschsprung's disease.

\section{Correspondencia}

Dr. Marco Antonio Ayala García

Correo electrónico: drmarcoayala@hotmail.com

\footnotetext{
Departamento de Investigación del Hospital Regional de Alta Especialidad del Bajío, León. Guanajuato, México.

Servicio de Cirugía General del HGSZ No. 10 del IMSS Delegación Guanajuato. Guanajuato, México.

Hospital General de Irapuato de la Secretaria de Salud del Estado de Guanajuato. Guanajuato, México.
} 